\title{
ZAJĘCIA Z HISTORII HISTORIOGRAFII W INSTYTUCIE HISTORII UNIWERSYTETU RZESZOWSKIEGO
}

\section{ABSTRACT}

History of historiography courses in the Institut of History at the University of Rzeszów

The Institute of History at the University of Rzeszów offers courses in the history of historiography as part of the first and the second cycle of studies. In there, the history of Polish historiography is discussed, contrasted with the background of Western European historiograhy from the earliest to contemporary times. The focus is on the main models for historical research, and the views of their most outstanding representatives are presented.

\section{KEYWORDS:}


W Instytucie Historii Uniwersytetu Rzeszowskiego prowadzone są zajęcia $\mathrm{z}$ historii historiografii $\mathrm{z}$ elementami metodologii historii oraz $\mathrm{z}$ historii historiografii XX wieku. Pierwszy z tych przedmiotów obowiązuje studentów historii na pierwszym stopniu (w wymiarze 30 godz.), drugi studentów historii studiów magisterskich (w wymiarze 45 godz.). Mają one formę konwersatoriów.

Na zajęciach na stopniu licencjackim, w związku z połączeniem historii historiografii z metodologią historii staramy się wiązać problematykę historiograficzną z metodologiczną. Odwołując się do aktualnego stanu badań omawiamy wszystkie epoki w rozwoju historiografii, z położeniem szczególnego akcentu na czasy oświecenia, romantyzmu, pozytywizmu oraz modernizmu i neoromantyzmu. Koncentrujemy się na historiografii polskiej, ale rozpatrujemy ją w ścisłym powiązaniu z historiografią europejską i na jej tle, zwłaszcza tej, która wywierała największy wpływ na polskie piśmiennictwo historyczne. Ze względu na wymiar godzin skupiamy się na ukazaniu głównych (najważniejszych) modeli uprawiania historii oraz zaprezentowaniu poglądów najwybitniejszych ich przedstawicieli. Wyodrębniamy szkoły naruszewiczowską, lelewelowską, krakowską, warszawską i lwowską, oraz nurt neoromantyczny. By przybliżyć studentom obraz dziejów narodowych kształtowany przez poszczególnych przedstawicieli polskiej historiografii omawiamy następujące szkice historyczne: Joachima Lelewela, Historyczna paralela Hiszpanii z Polska w XVI, XVII i XVIII wieku², Michała Bobrzyńskiego, Uwagi pierwsze ${ }^{3}$ oraz Władysława Konopczyńskiego, O wartości naszej spuścizny dziejowej ${ }^{4}$.

Kładziemy również nacisk na pokazanie zmian poglądów metodologicznych historyków. W tym celu omawiamy teksty źródłowe - autorstwa polskich historyków - w których prezentowane są ich poglądy na historię, jej przedmiot i funkcje (Adama Naruszewicza, Memoriat względem pisania historii narodowej ; J. Lelewela, Historyka ${ }^{6}$, Michała Bobrzyńskiego, Wimię prawdy dziejowej, rzecz o zadaniu historii i dzisiejszym

1 M.in. A. F. Grabski, Myśl historyczna polskiego oświecenia, Warszawa 1976; Tenże, Zarys historii historiografii polskiej, Poznań 2000; Tenże, Dzieje historiografii, Poznań 2003; J. Le Goff, Historia i pamięć, Warszawa 2007; G. G. Iggers, Historiografia XX wieku, Warszawa 2010; J. Maternicki, Historia i życie narodu. Poglady i postawy historyków polskich w XIX i XX w., Rzeszów 2009; Tenże, Walerian Kalinka (1826-1886) i jego badania nad epoka porozbiorowa, Rzeszów 2013; J. Serczyk, 25 wieków historii. Historycy i ich dzieła, Toruń 1994; J. Topolski, Od Achillesa do Beatrice de Planissolles. Zarys historii historiografii, Poznań 1998; A. Wierzbicki, Historiografia polska doby romantyzmu, Wrocław 1999; Złota księga historiografii lwowskiej XIX i XX wieku, t. I-II, Rzeszów 2007-2014; Historia w Uniwersytecie Lwowskim. Badania i nauczanie do 1939 roku, red. J. Maternicki, J. Pisulińska, L. Zaszkilniak, Rzeszów 2016.

2 J. Lelewel, Historia Polski nowożytnej, opr. J. Dutkiewicz, M. H. Serejski, H. Więckowska, Warszawa 1961, Dzieta, t. VIII, s. 215-263.

3 Historycy o historii. Od Adama Naruszewicza do Stanisława Kętrzyńskiego 1775- 1918, zebral, wstępem i komentarzem opatrzył M. H. Serejski, Warszawa 1963, s. 299-313.

4 Tamże, s. 596-610.

5 Tamże, 27-40.

6 J. Lelewel, Dzieła, t. II, Pisma metodologiczne, opr. N. Assorodobraj, Warszawa 1964, s. 178-208. 
jej stanowisku’ ${ }^{7}$ Władysława Smoleńskiego, Szkoły historyczne w Polsce. Główne kierunki pogladów na przesztośc ${ }^{8}$, Tadeusza Wojciechowskiego, Co to jest historia i po co się jej uczymy ${ }^{9}$, Stanisława Zakrzewskiego, Kultura historyczna $\left.{ }^{10}\right)$. Mamy nadzieję, że ten sposób prezentowania myśli metodologicznej, w toku analizy zagadnień historiograficznych, ułatwi studentowi zrozumienie trudnych dla niego zagadnień.

Historia historiografii XX wieku prowadzona w semestrze zimowym na I roku studiów II stopnia pozwala na prezentację historiografii polskiej bardziej szczegółowo. Przedstawiamy nie tylko ewolucję postaw metodologicznych i zapatrywań na dzieje Polski, ale również zmiany zachodzące w infrastrukturze nauki historycznej, jej obliczu ideowo-politycznym. Chcemy również ukazać udział polskiej historiografii w międzynarodowym życiu naukowym. Przed charakteryzacją dziejów historiografii polskiej obszernie nawiązujemy do tendencji występujących w nauce europejskiej i światowej. Analizujemy cechy historiografii modernistycznej przyglądając się takim kierunkom jak: Annales, Sozialgeschichte, New Economic History oraz historiografii marksistowskiej. Następnie koncentrujemy się na polskiej historiografii wydzielając okresy: 1918-1939; 1945-1948/49; 1949-1956, 1956-1989. Omawiamy również historiografię polską na emigracji".

Z kierunkami współczesnej myśli metodologicznej i z nowymi formami pisarstwa historycznego student ma możliwość zapoznania się na osobnych zajęciach - z metodologii historii. Są one prowadzone również na I roku studiów magisterskich, w semestrze letnim. Omawiamy: narratywizm, historię antropologiczną, historię wizualną, badania postkolonialne, oral history, badania genderowe, zwrot ku pamięci, historię rzeczy i środowiska.

W ośrodku rzeszowskim na studiach II stopnia prowadzone są również zajęcia konwersatoryjne: warsztat naukowy historyka historiografii w wymiarze 30 godzin. Jest on przedmiotem obligatoryjnym, na którym omawiając najważniejsze monografie i zbiory studiów historiograficznych dotyczące historiografii polskiej XIX i XX w. chcemy zapoznać studenta z terminologią i podstawą źródłową oraz metodami badawczymi stosowanymi przez historyków historiografii. Zajęcia te mają przede wszystkim na celu zachęcenie studenta do podjęcia samodzielnych badań nad historiografią.

7 Historycy o historii. Od Adama Naruszewicza do Stanistawa Kętrzyńskiego, s. 169-196.

8 Tamże, s. 345-356.

9 Tamże, s. 241-270

10 Tamże, s. 508-544.

11 Literatura zalecana studentom to m.in.: M. Górny, Przede wszystkim ma być naród. Marksistowskie historiografie w Europie Środkowo-Wschodniej, Warszawa 2007; P. Hübner, Nauka polska po II wojnie światowej - idee i instytucje, Warszawa 1987; J. Kocka, O historii społecznej Niemiec, Poznań 1997; Oskar Halecki i jego wizja Europy, red. M. Dąbrowska, Warszawa-Łódź 2012- 2014; J. Pomorski, Paradygmat „New Economic History”. Droga do “Nobla”, Lublin 1997; Z. Romek, Cenzura a nauka historyczna w Polsce 1944-1970, Warszawa 2010; T.P. Rutkowski, Nauki historyczne $w$ Polsce 1944- 1970. Zagadnienia polityczne i organizacyjne, Warszawa 2007; R. Stobiecki, Historia pod nadzorem. Spory o nowy model historii $w$ Polsce (II połowa lat czterdziestych - początek lat pięćdziesiątych, Łódź 1993; Tenże, Historiografia PRL. Ani dobra, ani mądra, ani piękna... ale skomplikowana, Warszawa 2007; Tenże, Klio na wygnaniu. Z dziejów polskiej historiografii na uchodźstwie w Wielkiej Brytanii po 1945, Poznań 2005. 